\title{
Deoxyribonucleic Acid Base Composition of Some Species within the Genus Candida
}

\author{
By A. STENDERUP AND A. LETH BAK \\ Institute of Bacteriology, University of Aarhus, Denmark
}

(Accepted for publication 18 December 1967)

\begin{abstract}
SUMMARY
The base composition of purified DNA from 18 species of the genus Candida was determined from the denaturation temperature, $T m$. A great genetic heterogeneity was found with a mean molar guanine +cytosine $(\% \mathrm{GC})$ composition ranging from $35 \cdot \mathrm{I}-57 \cdot 6 \%$.

Candida albicans, C. tropicalis, $C$. clausenii and C. stellatoidea showed essentially identical base composition $35 \cdot \mathrm{I}-35.7 \%$ GC. The highest values $(54 \cdot \mathrm{I}-57 \cdot 6 \% \mathrm{GC})$ were noted for $C$. catenulata, $C$. brumptii and $C$. zeylanoides. These three species also showed a compositional distribution of their DNA distinctly higher than the other species examined. The taxonomic and phylogenetic affinity between $C$. catenulata, $C$. brumptii and $C$. zeylanoides and the $C$.albicans group must on the basis of these investigations be seriously reconsidered. The rest of the species examined showed a wide range of mean $\%$ GC between the two clusters already mentioned. A variable degree of genetic affinity between these species and the $C$. albicans group cannot be excluded on the basis of the present examinations. Knowledge of DNA base compositions would appear to be of definite significance in the taxonomy of yeasts.
\end{abstract}

\section{INTRODUCTION}

Recent progress in molecular biology has rendered it possible to compare some properties of the deoxyribonucleic acid (DNA) molecules in different micro-organisms and has in this way given a better foundation of taxonomy, the latter being theoretically based on similarities within genomes (Marmur, Falkow \& Mandel, 1963). The methods most widely used are: (I) determination of DNA base composition, and (2) assessment of base-sequence homology by means of DNA-DNA or DNA-RNA hybrid experiments. A determination of base composition will most naturally be the first approach to the problem, because great similarity in base composition is a prerequisite for extensive base-sequence homology and thus also for similarity in phenotype. Determination of base composition has been shown to be of considerable value in bacterial taxonomy. The main reason for this is the wide variation in mean base composition (most frequently expressed as the mean molar percentages (guanine + cytosine) ( $\% \mathrm{GC})$ ) found between the different members of the bacterial world $(25-75 \% \mathrm{GC})$ as opposed to the narrow compositional distribution of DNA molecules within the individual bacterial cell (Sueoka, 196I). Whether similar conditions are valid as regards yeasts cannot be assessed, as only scarce information of base composition in these organisms is available. However, by determining the base composition in species from different genera of fungi including a few yeast species, Storck (1966) found a fairly wide variation of mean \% GC. On the basis of these 
determinations and a very few others, culled from the literature (referred to in his paper), he suggested that knowledge of base composition might be of value in the taxonomy of fungi.

The present paper deals with the base composition in different species of the genus Candida and gives an assessment of the value of the determinations in yeast taxonomy. We have chosen this genus for study because of its heterogeneity. The main characteristic of the genus is the ability of its members to form a pseudomycelium. This feature may be difficult to observe because the ability to produce this character varies within and between species and is dependent on the conditions of cultivation. The genus comprises species of very different morphology and ecological status. Some species are strong fermenters; others ferment only weakly or fermentation ability may be absent. Some species assimilate nitrate; most do not. Their ability to assimilate carbon compounds is also varied.

\section{METHODS}

Organisms. All species investigated except Candida atmosphaerica and C. clausenii, obtained from the Czechoslovak Collection of Micro-organisms (CSAV), were obtained from the Centraalbureau voor Schimmelcultures, Baarn, Netherlands (CBS). Their names and species numbers are listed in Table I. All species were reclassified according to the principles given by Lodder \& Kreger-van Rij (1952).

Cultivation of organisms. All species were grown in 7.51. quantities of a liquid medium containing $(\%, w / v)$ : glucose $5 \cdot 0$, peptone (Orthana) $\mathrm{I} \cdot 0$, yeast extract (Oxoid) $0.5, \mathrm{~K}_{2} \mathrm{HPO}_{4} \mathrm{O} \cdot \mathrm{I}$; adjusted to $\mathrm{pH} 5.6$. Growth took place at room temperature (about $23^{\circ}$ ) in Io 1 . Pyrex flasks, vigourously aerated. After growth for I-3 days, the yeasts were harvested by centrifugation in a Sorvall continuous flow system at $4^{\circ}, 10,000 \mathrm{~g}$, $500 \mathrm{ml} . / \mathrm{min}$. Tests for bacterial contamination were made by direct microscopy and plating on blood agar (incubated at $25^{\circ}$ and $37^{\circ}$ ) immediately before centrifugation.

Preparation of pure DNA. The organisms (at least $50 \mathrm{~g}$. wet weight) were washed three times in cold saline EDTA $(0.15 \mathrm{M}-\mathrm{NaCl}+0 . \mathrm{I}$ M-ethylenediaminetetra-acetate (EDTA), pH 8) and disrupted with a Branson sonifier, Model S 75, operating at maximal energy. The sonic treatment was done on $50 \mathrm{ml}$. portions of a $10 \%$ suspension of the yeast paste in saline EDTA to which were added glass beads (Ballotini, $0.1 \mathrm{~mm}$.). Each portion was treated for $5 \mathrm{~min}$. on an ice-bath. Sonic treatment was chosen as the most convenient method for routine use. Judging from an experiment by Marmur (I96I) on sonic treatment of pneumococci a molecular weight of the DNA of about $\mathrm{I} \times 10^{6} \mathrm{might}$ be anticipated.

For extraction of pure DNA from the partially broken organism suspension the method of Marmur (196I) was followed throughout except for the introduction of an additional ribonuclease treatment and isopropanol precipitation early in the procedure to remove the bulk of the RNA and polysaccharide. The final fibrous precipitate of pure DNA was dissolved in saline citrate (0.15 M- $\mathrm{NaCl}+0.015 \mathrm{M}$-trisodium citrate; $\mathrm{pH} 7 \cdot 0$ ) and stored at $4^{\circ}$ over a few drops of chloroform.

Determination of DNA base composition by thermal denaturation. An automatically recording thermospectrophotometer was set up according to the principles given by Szybalski \& Mennigmann (1962) and De Ley \& van Muylem (1963). The arrangement consisted of an Unicam SP 800 ultraviolet spectrophotometer, equipped with a thermostatted cuvette holder (Unicam, SP 874). The cuvette holder was heated from a 
circulating water bath, the temperature of which could be raised at a constant rate. The temperature was measured in a control cuvette containing the platinum resistance of a Gilford linear thermosensor. Temperature and extinction were recorded on the $x$ and $y$ axes, respectively, of a Moseley $x-y$ autograph, Model 2D-4M. The temperature was increased by $0.2^{\circ} \mathrm{min}$, and the extinction recorded in the temperature interval from 60 to $100^{\circ}$. One sample containing pure DNA in saline citrate and adjusted to give an extinction of about 0.7 (approximately $28 \mu \mathrm{g}$. DNA/ml.) was heated in each experiment. The blank contained adenine of the same extinction in the same buffer to correct for thermal expansion. The temperature standards on the thermosensor was checked against a calibrated thermometer, and the reliability of the method was checked by comparing the measured $T m$ values for several specimens of bacterial DNA with those recorded in the literature.

The $T m$ values were determined as the mid-point of the extinction-temperature curves between extinction at $69^{\circ}$ and extinction at maximal hyperchromicity (Rogul, McGee, Wittler \& Falkow, 1965). The mean base composition, expressed as \% GC was calculated from $T m$ by the formula: $\% \mathrm{GC}=(\mathrm{Tm}-69 \cdot 3) / 0 \cdot 4 \mathrm{I}$ (Marmur \& Doty, 1962).

Table I. 'Melting point' Tm, with standard deviation, and the mean base composition expressed as \% GC of pure DNA from species of the genus Candida

For methods, see text.

\begin{tabular}{|c|c|}
\hline Species & Source \\
\hline $\begin{array}{l}\text { C. albicans } \\
\text { C. tropicalis } \\
\text { C. clausenii } \\
\text { C. stellatoidea }\end{array}$ & $\begin{array}{l}\text { CBS } 2712 \\
\text { CBS } 120 / 5 \\
\text { CSAV 29-3I-I } \\
\text { CBS } 1905\end{array}$ \\
\hline $\begin{array}{l}\text { C. pelliculosa } \\
\text { C. truncata } \\
\text { C. } \text { krusei } \\
\text { C. atmosphaerica } \\
\text { C. parapsilosis } \\
\text { C. melinii } \\
\text { C. pseudotropicc lis } \\
\text { C. tenuis } \\
\text { C. utilis } \\
\text { C. pulcherrima } \\
\text { C. lipolytica }\end{array}$ & $\begin{array}{l}\text { CBS 605 } \\
\text { CBS I899 } \\
\text { CBS 573 } \\
\text { CSAV 29-50-I } \\
\text { CBS 604 } \\
\text { CBS 66I } \\
\text { CBS 607 } \\
\text { CBS 6I5 } \\
\text { CBS 621 } \\
\text { CBS 610 } \\
\text { CBS 599 }\end{array}$ \\
\hline $\begin{array}{l}\text { C. brumptii } \\
\text { C. catenulata } \\
\text { C. zeylanoides }\end{array}$ & $\begin{array}{l}\text { CBS } 564 \\
\text { CBS } 565 \\
\text { CBS } 619\end{array}$ \\
\hline
\end{tabular}

$T m\left({ }^{\circ} \mathrm{C}\right) \pm$ s.D.
$83.7 \pm 0.05$
$83.6 \pm 0.10$
$83.6 \pm 0.10$
$83.9 \pm 0.15$
$84.4 \pm 0.15$
$84.4 \pm 0.15$
$85.5 \pm 0.05$
$85.6 \pm 0.10$
$86.0 \pm 0.15$
$86 \cdot 1 \pm 0.10$
$86.2 \pm 0.10$
$87.4 \pm 0.15$
$88 \cdot 1 \pm 0.10$
$89.0 \pm 0.15$
$89.6 \pm 0.00$
$91 \cdot 5 \pm 0.10$
$91 \cdot 7 \pm 0.05$
$92.9 \pm 0.15$

$\% \mathrm{GC}$

The species of Candida examined, together with the thermal denaturation temperature $T m$, and the mean base composition \% GC, are presented in Table I. Figure I gives examples of denaturation curves for three species. The $T m$ values are averages of at least four determinations. The standard deviation of the mean $T m$ was in most cases $0.10-0.15^{\circ}$, corresponding to a deviation in $\%$ GC of $0.25-0.40$.

In most cases the denaturation curves showed a regular $S$ shape indicating an unimodal Gaussian or nearly Gaussian distribution of the DNA molecules. However, a skewness to the left or even a small shoulder at the initial part of the denaturation 
curves was seen for some species. The two most pronounced examples are given in Fig. 2. This irregularity may suggest that a smaller DNA fraction is present in the DNA preparations from these species. The $T m$ values of this possibly satellite DNA are very low (below $80^{\circ}$ ). A similar pronounced AT-type DNA in Saccharomyces cere-

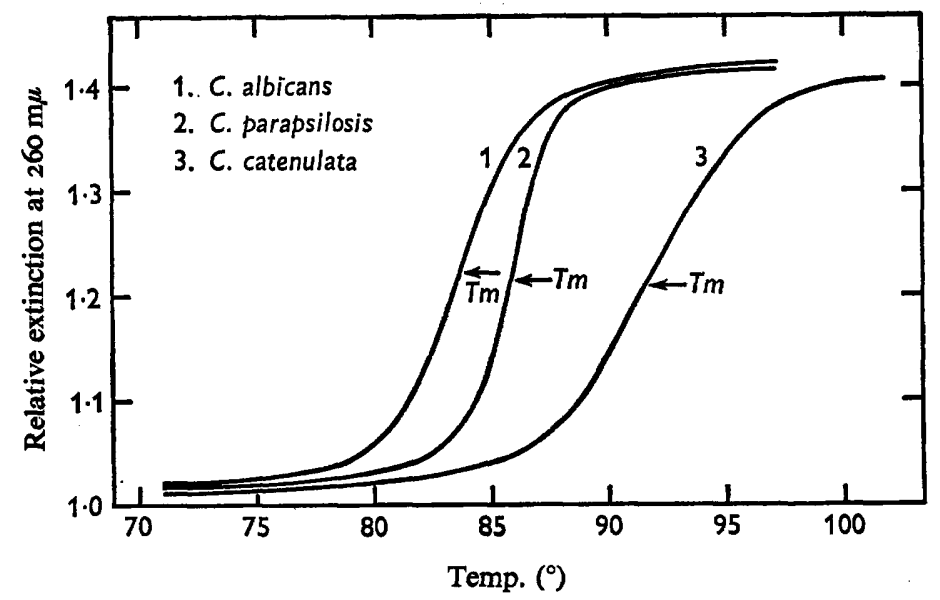

Fig. 1. Examples of thermal denaturation curves of DNA of species selected from each of the three groups in Table I. The results are expressed as the relative absorbance at $260 \mathrm{~m} \mu$ (see text) versus temperature. The curves are displaced vertically to allow better resolution.

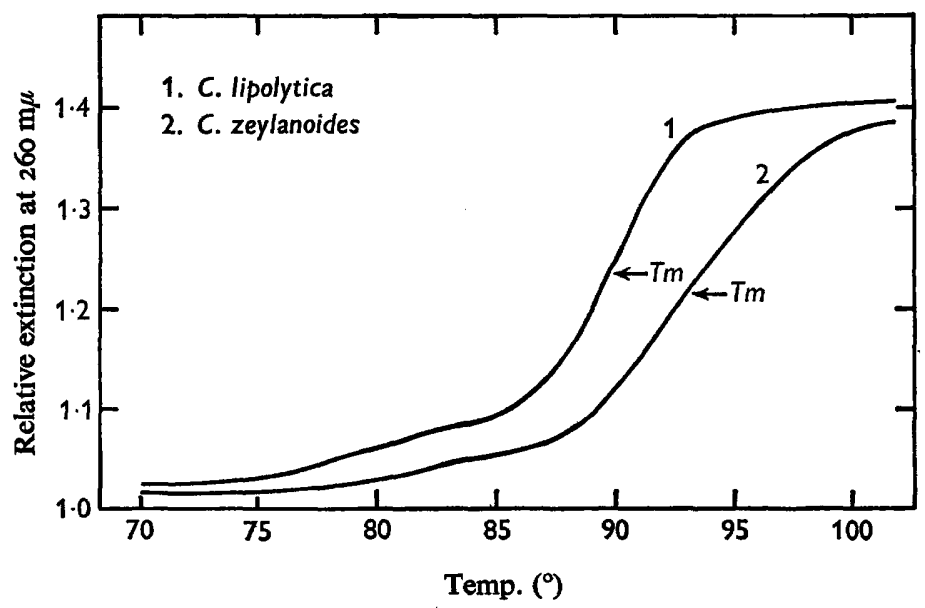

Fig. 2. Thermal denaturation curves of DNA fo two species showing two components, a major 'nuclear' DNA, and a minor presumably mitochondrial DNA. The results are expressed as in Fig. I.

visiae and $S$. carlsbergensis has been found to correspond to a double helical mitochondrial DNA by Tewari, Jayaraman \& Mahler (1965) and Corneo, Moore, Sanadi, Grossman \& Marmur (1966).

The $T m$ values in Table $\mathrm{I}$ are corrected to correspond to the main 'nuclear' DNA. The correction was lower than $0.5^{\circ}$ in all instances, usually $0.2^{\circ}$. 


\section{DISCUSSION}

The mean base compositions are seen to cover a wide range $(35 \cdot \mathrm{I}-57 \cdot 6 \% \mathrm{GC})$ indicating a pronounced genetic heterogeneity among the species investigated. The lowest $\% \mathrm{GC}$ values are seen for Candida albicans, $C$. tropicalis, $C$. clausenii and $C$. stellatoidea. These four species which, from a conventional point of view, must be regarded as very closely related, show essentially identical base composition $\left(35^{\circ} \mathrm{I}-\right.$ $35.7 \% \mathrm{GC})$. At the other extreme is found a relatively narrow cluster $\left(54^{\circ} \mathrm{r}-57.6 \% \mathrm{GC}\right)$ composed of $C$. catenulata, $C$. brumptii and $C$. zeylanoides. These three species also differ from the other species in having a distinctly greater heterogeneity among their DNA molecules. When the standard deviation $\sigma$ of the compositional distribution of DNA molecules around the mean $\% \mathrm{GC}$ was calculated by using the equation of Doty, Marmur \& Sueoka (1959), a value greater than $5 \%$ GC was found for these species. For the other species the $\sigma$ values varied between $0.5-3.0 \% \mathrm{GC}$, comparable with the intermolecular heterogeneity in many bacteria. However, the taxonomic significance of this parameter should be evaluated with great caution. While $T m$ is not influenced by a decrease in molecular weight down to at least 600,000 (Marmur \& Doty, 1962), this need not be so as regards the $\sigma$ value. A greater intramolecular than intermolecular heterogeneity will thus increase the value of $\sigma$ when the DNA molecules are degraded.

The variation in $\sigma$ among the yeasts studied here may result from a difference in molecular weight of the DNA caused by the differences in the ease with which the different species were disrupted during ultrasonic treatment. If this be so, the different $\sigma$ values must be an indication of a pronounced non-random distribution of bases in the DNA molecules. However, the high values of $\sigma$ within the high $T m$ group were reproducible and constantly at a higher value than was the case within the rest of the species examined. On the basis of these two factors, the high mean $\% \mathrm{GC}$ and the great compositional distribution of the DNA molecules, the placing of Candida catenulata, $C$. brumptii and $C$. zeylanoides in the same genus as the other species must be seriously reconsidered. These species may have a different phylogenetic origin.

The rest of the species examined cover a wide range $(36 \cdot 8-49.6 \% \mathrm{GC})$ between the two clusters already mentioned. On the basis of our present knowledge it seems premature to discuss the relation of these species to the Candida albicans group. However, on account of the presumed non-random distribution of bases and the fact that the $\sigma$ values calculated by the equation of Doty et al. (1959) presumably underestimate the actual degree of possible common DNA molecules (De Ley, Park Tijtgat \& van Ermengen, 1966), a certain degree of genetic affinity between the different members of these two groups cannot be excluded.

The work was aided by grant from the Danish State Research Foundation.

\section{REFERENCES}

Corneo, G., Moore, C., Sanadi, D. R., Grossman, L. I. \& Marmur, J. (1966). Mitochondrial DNA in yeast and some mammalian species. Science, N.Y. r51, 687.

De LeY, J. \& VAN MuYLeM, J. (1963). Some applications of deoxyribonucleic acid base composition in bacterial taxonomy. Antonie van Leeuwenhoek 29, 344.

De Ley, J., Park, I. W., Tijtgat, R. \& van ERmengen, J. (1966). DNA homology and taxonomy of Pseudomonas and Xanthomonas. J. gen. Microbiol. 42, 43. 
Doty, P., MARMUR, J. \& SUEOKA, N. (1959). The heterogeneity in properties and functioning of deoxyribonucleic acids. Brookhaven Symp. Biol. r2, I.

LODDER, J. \& KREGer-van RiJ, N. J. W. (I952). The Yeasts. A Taxonomic Study. Amsterdam: North Holland Publishing Co.; New York: Interscience Publishers Inc.

MARMUR, J. (1961). A procedure for the isolation of deoxyribonucleic acid from micro-organisms. J. molec. Biol. 3, 208.

MARMUR, J. \& DoTY, P. (1962). Determination of the base composition of deoxyribonucleic acid from its thermal denaturation temperature. J. molec. Biol. 5, 109.

MarmuR, J. Falkow, S. \& MANDEL, M. (1963). New approaches to bacterial taxonomy. A. Rev. Microbiol. 17, 329.

Rogul, M., McGee, Z. A., Wittler, R. G. \& Falkow, S. (1965). Nucleic acid homologies of selected bacteria, L forms, and Mycoplasma species. J. Bact. 90, I200.

STORCK, R. (I966). Nucleotide composition of nucleic acids of fungi. II. Deoxyribonucleic acids. J. Bact. 9r, 227.

SuzokA, N. (196I). Variation and heterogeneity of base composition of deoxyribonucleic acids: a compilation of old and new data. J. molec. Biol. 3, 31.

SZYBalski, W. \& Menningmann, H. D. (1962). The recording thermospectrophotometer, an automatic device for determining the thermal stability of nucleic acids. Analyt. Biochem. 3, 267.

Tewari, K. K., Jayaraman, J. \& Mahier, H. R. (1965). Separation and characterization of mitochondrial DNA from yeast. Biochem. Biophys. Res. Commun. 21, I4I. 